\title{
A Field Application Measuring Healthcare Employees' Perceptions Toward Corporate Entrepreneurship
}

\author{
Çiğdem Dikmen ${ }^{1}$ \\ Bilim University
}

\begin{abstract}
Today, organizations that not only develop new and creative ideas, but that also offer new services to customers are able to continuously renew themselves and become leaders in high-competition environments. Organizations that offer new products and services to their customers might be able to survive, grow, achieve their goals, meet customer demands, and thus they obtain a great advantage. Therefore, the success and survival of today's healthcare organizations within a highly competitive environment may be achieved by adopting continuous innovation as a core competence. It is necessary for organizations to be leaders in innovation in order to increase the value of healthcare services. Innovations generated in healthcare services will create both value for patient and competitive advantage for organization. Consequently, the phenomenon of corporate entrepreneurship underlies offering new services in the healthcare sector and being a leader. This study aims to determine which factors influence the perceptions toward corporate entrepreneurship held by doctor groups and nurse groups working in a University Hospital Research and Application Center, which might be seen as a pioneering example of "corporate entrepreneurship" in Turkey. The questionnaire form used in the study, of whose reliability coefficient was found to be .884 , shows consistency with prior studies conducted using the conceptual dimensions of the corporate entrepreneurship interaction model, and indicates statistically significant findings. Thus, in this study, the phenomenon of corporate entrepreneurship, which constitutes the conceptual framework of this study, will be explained in a theoretical dimension. Moreover, the methodology, findings, conclusion, and recommendations will be discussed.
\end{abstract}

Keywords

Corporate entrepreneurship • Physicians $\bullet$ Nurses $\bullet$ Hospital $\bullet$ Integrated Practice Unit (IPU)

JEL Classification

M10

1 Correspondence to: Çiğdem Dikmen, School of Health, Istanbul Bilim University, Yazarlar Sok. No: 17 Esentepe Şişli, İstanbul Turkey. Email: cigdem.dikmen@istanbulbilim.edu.tr

Citation: Dikmen, Ç. (2016). A field application measuring healthcare employees' perceptions toward corporate entrepreneurship. Sanitas Magisterium, 2, 23-40. http://dx.doi.org/10.12738/SM.2016.1.0016 
Organizations are required to continuously renew and change their services, systems, processes, and strategies in order to both adjust to the rapid changes occurring within the external environment and to be a leader within the market. Moreover, the success and survival of today's healthcare organizations within a highly competitive environment may only be achieved by adopting continuous innovation as a core competence. Therefore, innovation and effective competition skills are seen as core competencies that increase businesses' success and profits. Although establishing innovation orientation in an organization is difficult, the creative ideas and innovation-supporting behaviors of manager in the organization may lead to it being institutionalized.

\section{Corporate Entrepreneurship}

The concept of corporate entrepreneurship (Covin \& Miles, 1999; Dess, Lumpkin, \& McGee, 1999, p. 85; Hornsby, Kuratko, \& Zahra, 2002; Kuratko, 2013; Slevin \& Covin, 1990, p. 45; Vesper, 1984; Zahra, 2007) is used to describe tendencies and behaviors of entrepreneurship. It is defined as the development of new businesses and creating value within an organization by using new combinations of business resources.

Being innovative is perceived not only as a characteristic that provides competitive advantages, but also as a fundamental quality for one who wishes to adapt to and survive in his ever-changing environment. Although being innovative is not the only characteristic necessary to create competitive advantage, it is necessary to ensure equality in competition. Entrepreneurship, on the other hand, is a dynamic vision process, which requires the application of creative ideas with the help of energy, passion for creativity, and new ideas (Kuratko, 2013). Therefore, due to constantly increasing competition in the business environment, the concept of corporate entrepreneurship, in addition to the concepts of entrepreneurship and innovation, becomes important for anyone wishing to gain and maintain a competitive advantage. Since this is the case numerous studies related to this concept have been conducted (Hayton \& Kelley, 2006).

Corporate entrepreneurship is defined as leading employees to change and to become more innovative by founding another organization within the business, and thus making the organization successful. Corporate entrepreneurship involves every type of formal entrepreneurship activity performed within an organizational structure (Greene, Brush, \& Hart, 1999, p. 104). Formally, corporate entrepreneurship delineates the state of a organization, where entrepreneurial and innovative activities have become essential parts of the organizational strategy. In other words, they are supported and accepted by top management. Corporate entrepreneurship is based on the idea that a business concentrates and devotes its resource commitments for the purpose of carrying out innovative activities in the form of products, processes, and organizational innovations (Hornsby et al., 2002). 
Three types of activities are emphasized in corporate entrepreneurship: corporate venturing, intrapreneurship, and firm-level entrepreneurship (Covin \& Miles, 1999).

\section{Corporate Venturing}

Corporate venturing refers to creating a new business start-up by the present firm. In the organizational structure, the internal corporate ventures are connected to the parent company. The employees might create these ventures. They can also be established by purchasing of another company. The main characteristics of these businesses are that they (1) involve an activity new to the organization, (2) have a significantly higher risk of failure or of large losses than the organization's base business, and (3) were established for the purpose of increasing sales, profit, productivity, and quality (Block \& MacMillan, 1995, p. 14).

One of the most important factors in determining the success of a business is how related the intra-firm business's scope is with the activities of the main business in terms of product, market, and/or technology. Innovative ideas generated by members of the organization must be consistent with the organization's current capabilities. Otherwise, if an organization attempts to pursue an opportunity for which it does not have the necessary capabilities, it might result in a net decrease in the organization's overall performance. On the other hand, if the relationship between current capabilities and opportunities is kept too tight, learning by creating innovations and gaining experience in new fields, these being the main aims of corporate entrepreneurship, might not be an attainable goal (Floyd \& Wooldridge, 1999, p. 123).

\section{Intrapreneurship}

The concept of intrapreneurship is defined as being the process by which individuals inside an organization pursue opportunities, develop ideas, and put these ideas into practice. Perhaps the broadest definition of intrapreneurship is that "intrapreneurship is entrepreneurship within an existing organization." Within the framework of intrapreneurship activities, members of an organization first develop a vision related to new ideas and then construct a business plan involving substantial activities in the direction of this vision. Members of the organization play a variety of roles while bringing new ideas into fruition. These roles include that of an inventor, intrapreneur, sponsor, and protector. Although the inventor develops the draft proposal related to the product or service, he does not solve the problem of turning the developed idea into an efficient business. The intrapreneur, with a realistic perspective, turns the developed idea into a project related to business. Yet, the intrapreneur is incapable of customizing the developed project according to organization policies. The sponsor eliminates problems by removing organizational obstacles faced by the intrapreneur. Lastly, the protector is the one who gives top management approval to the project and ensures the actualization of the new idea (Pinchot, 1986, pp. 48-49). 
As an on-going process within an existing firm, intrapreneurship refers to the maintenance of innovative activities and orientation, on the one hand, and to the development of new services, new technologies, management techniques, and strategies for obtaining competitive advantage, on the other (Antoncic \& Hisrich, 2001).

\section{Firm Level Entrepreneurship}

Firm level entrepreneurship is defined as spreading the entrepreneurial philosophy throughout the entire organization and making the main method of doing business for the firm. Firm level definitions generally focus on organizational size (number of employees) and organizational tradition (Lane, John, Marburger III, \& Shipp, 2011, p. 220).

The most distinct characteristics of organizations applying firm level entrepreneurship are that such organizations offer new products-services to the market more frequently, have a higher tendency to take risks, and act before competitors do by adopting a proactive approach in putting managerial processes into practice.

\section{Types of Corporate Entrepreneurship Strategies}

Covin and Miles evaluate corporate entrepreneurship strategies using four main themes: (1) sustained regeneration, (2) organizational rejuvenation, (3) strategic renewal, and (4) domain redefinition (1999).

\section{Sustained Regeneration}

Firms that engage in sustained regeneration are either those that regularly and continuously introduce new products and services to the market or those that enter new markets (Covin \& Miles, 1999). These new products and services are intended to capitalize on latent and under-exploited market opportunities. According to Hamel and Prahalad, firms that focus only on the needs of current customers will not be able to implement the innovations necessary to become a leading firm in the future. Truly innovative organizations must focus on those needs that have not yet been expressed by customers, on the one hand and must target new customers by offering new products and new services, on the other (1998, p. 102).

\section{Organizational Rejuvenation}

The concept of organizational rejuvenation is used to refer to the phenomenon of corporate entrepreneurship whereby an organization seeks to sustain or improve its competitive standing by altering its internal processes, structures, and capabilities (Covin \& Miles, 1999). This concept is also referred to as organizational renewal. Organizational rejuvenation is the process of starting, creating, and initiating changes necessary for problem solving, on the one hand, and adapting to new conditions and reaching 
organizational maturity, on the other. According to this approach, entrepreneurship activities aim to renew the organization itself, not its strategy. As a result of changes in the organizational environment, organizations experience a need for change and rejuvenation. Organizations expand due to the implementation of new business processes, which in turn cause new organizational problems to appear. In this situation, a redesign of every aspect of the organizational structure becomes the main issue.

\section{Strategic Renewal}

The main purpose of strategic renewal is to rearrange an organization's relationship with its environment so as to develop competitive bases. Unlike organizational rejuvenation, strategic renewal is based on changing organizational strategy. During strategic renewal stages, an organization changes its strategies and practices, redefining its relationship with its competitors. In fact, new strategies constitute strategic renewal, as long as they represent the organization's repositioning within the competitive environment (Wilkinson \& Kannan, 2013, p. 290).

\section{Domain Redefinition}

Domain redefinition is based on applying a proactive approach so as to trigger development of a new product-market field, one that competitors have been unable to realize. This strategy provides such advantages as being the first-mover and relocating competition to a newly develop area in which competitors' capabilities are insufficient.

When the characteristics of different types of corporate entrepreneurship strategies are examined, it is argued that entrepreneurial activity occurs more frequently for a businesses that adopts a strategy consisting of continuous innovation (Covin \& Miles, 1999).

\section{Characteristics of Corporate Entrepreneurship Strategy}

Senior managers constantly seek potential innovations and how to implement them into future business activities so as to ensure their long-term survival and to increase their overall value. By having a competitive advantage business can earn higher profits than their competitors as long as they are able to produce and offer products and services different from those already available on the market. Therefore, competitive advantage is mainly based on creating new products and services.

Table 1 shows the focus of each form of corporate entrepreneurship as well as the typical basis for competitive advantage associated with each form. 
Table 1

Some Key Attributes of the Four Forms of Corporate Entrepreneurship (Covin \& Miles, 1999, p. 57)

\begin{tabular}{|c|c|c|c|c|}
\hline $\begin{array}{l}\text { Type of } \\
\text { Strategy }\end{array}$ & Focus of Strategy & $\begin{array}{l}\text { Basis for } \\
\text { Competitive } \\
\text { Advantage }\end{array}$ & $\begin{array}{l}\text { Frequency of New } \\
\text { Entrepreneurial } \\
\text { Activities }\end{array}$ & $\begin{array}{c}\text { Magnitude of Negative Impact } \\
\text { if New Entrepreneurial Act is } \\
\text { Unsuccessful }\end{array}$ \\
\hline $\begin{array}{c}\text { Sustained } \\
\text { Regeneration }\end{array}$ & $\begin{array}{l}\text { New products/services } \\
\text { or new markets }\end{array}$ & Differentiation & High & Low \\
\hline $\begin{array}{l}\text { Organizational } \\
\text { Rejuvenation }\end{array}$ & The Organization & $\begin{array}{c}\text { Cost } \\
\text { Leadership }\end{array}$ & Medium & Medium \\
\hline $\begin{array}{l}\text { Strategic } \\
\text { Renewal }\end{array}$ & Business Strategy & $\begin{array}{l}\text { Varies with } \\
\text { Specific Form } \\
\text { Manifestation }\end{array}$ & Low & High \\
\hline $\begin{array}{c}\text { Domain } \\
\text { Redefinition }\end{array}$ & $\begin{array}{c}\text { Creation and } \\
\text { Exploitation of } \\
\text { Product-Market Arenas }\end{array}$ & $\begin{array}{c}\text { Quick } \\
\text { Response }\end{array}$ & Infrequent & $\begin{array}{l}\text { Varies in terms of Specific } \\
\text { From Manifestation and } \\
\text { Contextual Considerations }\end{array}$ \\
\hline
\end{tabular}

\section{Corporate Entrepreneurship Model}

The corporate entrepreneurship model argues that entrepreneurial behavior is a result of the interactions between individuals, organizational characteristics, and the external environment (Figure 1). In the organizations, in which these factors

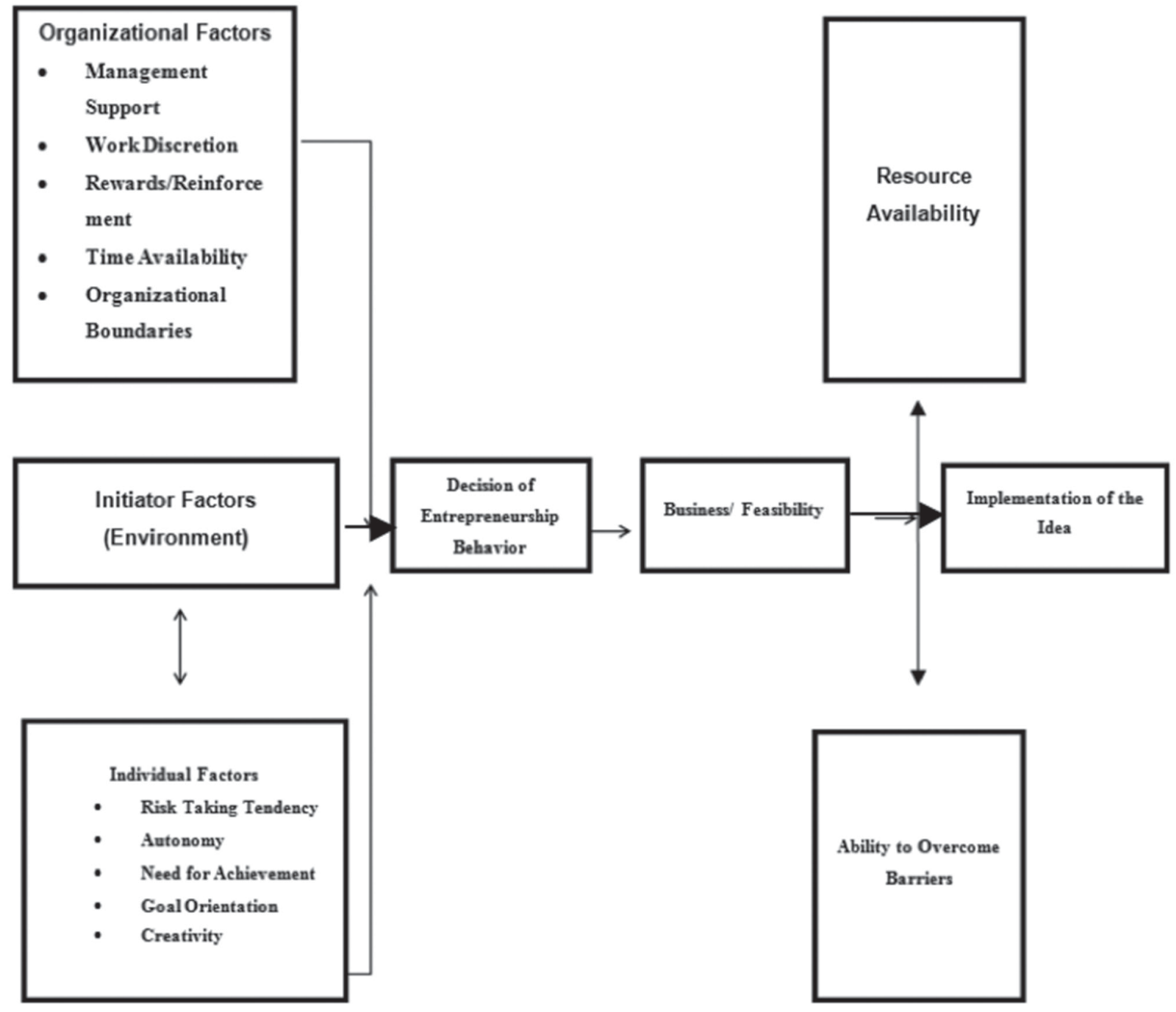

Figure 1: Corporate entrepreneurship model (Hornsby, Naffziger, Kuratko, \& Montagno, 1993, p. 31). 
harmoniously come together, corporate entrepreneurship is implemented as an organizational strategy (Hornsby et al., 2002).

\section{External Environment}

Two driving factors indicated in corporate entrepreneurship strategies are whether instability and heterogeneity exist in the external environment and whether there exists a higher risk of external threats. Certain developments, such as increasing global competition, downsizing businesses, and rapid changes in technology, have made innovation a necessity for businesses (Dess et al., 1999, p. 85). Dynamic environments, which cause to changes in competition bases, have given the chance of increased financial performance to medium-sized businesses adopting an entrepreneurial management style. The success of small and medium sized businesses leads large businesses to evaluate their corporate entrepreneurship strategy.

Entrepreneurship literature argues that entrepreneurship behaviors within an organization will gain more prevalence in those sectors in which external competition is high. On the other hand, since in those sectors in which external competition level is low, the reliability of predictions about the future is high, it is easier to pursue opportunities (Slevin \& Covin, 1990, p. 45).

Prior studies show that the use of corporate entrepreneurship as a business strategy is more prevalent in highly competitive sectors. Moreover, it is argued that if an organization can use its strengths to respond to the opportunities in the environment, its chances of gaining and sustaining a competitive advantage will be higher (Ülgen \& Mirze, 2004, p. 161).

\section{Organizational Characteristics}

Although some businesses have sufficient financial resources, they cannot make innovation into a usable, continuous business strategy. According to prior studies, certain organizational characteristics are needed in order to foster creative individuals being able not only to use their skills, but also to come up with innovative ideas. The innovativeness of the employees depends on the support of the entrepreneurial behaviors by these organizational characteristics. For organizations whose managers' motivations are positively supported by organizational factors that support a corporate entrepreneurship strategy, it is more likely to see creative and entrepreneurial behaviors implemented as continuous and sustainable business strategies.

Organizational factors that support the success of corporate entrepreneurship activities include: organizational structure (Russel, 1999, p. 65), organizational resources, the legitimization level of entrepreneurial behaviors within the organization (Greene et al., 1999, p. 104), organizational environment (top management support, 
organizational policies, culture, and norms), risk taking tendency, autonomy (Amabile \& Conti, 1999, p. 631), appropriate reward system, and intra-organizational boundaries (Hornsby et al., 1993, p. 31).

\section{Personal Characteristics}

Personal factors, which are thought to lead individuals within the organization to engage in entrepreneurial behaviors, are generally similar to individual entrepreneurship characteristics. These characteristics consist of creativity, a risktaking tendency, autonomy, the need for achievement, and goal orientation (Hornsby et al., 1993, p. 32).

\section{Corporate Entrepreneurship in Hospitals}

In the healthcare sector, since competition continues to increase, obtaining a competitive advantage over rivals has become an important issue for hospitals. In order to survive over the long-term, to increase value, and to offer a variety of different services, hospitals' top management must encourage their employees to use their creative skills (Miles, Miles, \& Snow, 2006), manage creativity effectively, see employees' ideas as valuable, and create an organizational culture in which flexible and open communication encouraging employees to take initiatives exists. Today, organizations that develop and offer new products and ideas will renew themselves and become leaders in high competition environments. Taking advantage of creative ideas, organizations that offer new products and services to their customers are more likely to survive, to achieve their goals, and to meet customer demands.

In order to increase the value of healthcare services, organizations must be leaders of innovation. Therefore, providing more effective and efficient healthcare services may only be realized through the development of new services and processes (Guo, 2003).

Argued as a reformative strategy for healthcare services, Porter and Teisberg's model (Porter, 2014, p. 6; Porter \& Teisberg, 2006) is based on six independent factors necessary for moving to "a high-value healthcare system." These independent factors are (1) organizing around patients' health problems instead of organizing around medical specialty, (2) measuring costs and consequences for each patient, (3) moving to a lump sum payment system for treatment cycles, (4) integrating treatment systems, (5) integrating geographical access areas, and (6) establishing efficient information technology platforms. After such organizations as the Cleveland Clinic in the U.S. or the Schön Clinic in Germany initiated certain changes associated with a high-value healthcare system increases were witnessed in their productivity and market share.

In Turkey, the Down Syndrome Center was put into practice through forming Integrated Practice Units (units that are concerned not only with diseases, but also with 
complications and patients' relatives) in Istanbul Bilim University Şişli’s Florence Nightingale Research and Practice Center March 21, 2014. In integrated practice units, a special team formed of both clinical and not clinical personnel provides full-cycle service depending on patients' conditions. Patient-centered healthcare services offered in Istanbul Bilim University Şişli's Florence Nightingale Research and Practice Center have enabled patients to receive all services under a single roof for the first time.

Due to its pioneering status in Turkey's healthcare sector. Istanbul Bilim University Şişli's Florence Nightingale Research and Application Center was chosen to be field of application for this research.

\section{Purpose}

The aim of this study is to measure how medical staff employed in Istanbul Bilim University Şişli's Florence Nightingale Research and Application Center perceive the factors influencing entrepreneurship behaviors in the Corporate Entrepreneurship Model of Horsby et al. (1993, pp. 31-32).

\section{Method}

In industrialized countries, the importance of healthcare organizations increases in prominence as the quality of life increases. When the conditions of increasing competition environment are considered, healthcare organizations, just like other businesses, need powerful strategies to be superior to other organizations and ensure survival.

\section{Research Design}

The questionnaire form that was developed based on the factors influencing entrepreneurship behaviors in Corporate Entrepreneurship Model of Horsby et al. (1993) was constructed as a 5-Point-Likert scale (1=strongly disagree, $2=$ disagree, $3=$ neither agree nor disagree, $4=$ agree, $5=$ strongly agree). The reliability coefficient of the scale was found to be .884 , and according to the factor analyses, it was seen that the conceptual dimensions measured in this study are consistent with the theoretical content discussed in the existing literature.

\section{Analysis}

This study took as its unit of analysis the healthcare staff employed in Istanbul Bilim University's Şişli Florence Nightingale Research and Application Center

\section{Data Analysis}

The data collected from the surveys were transferred to a computer. After performing all the necessary error checks, 210 valid surveys were obtained. In 
order to evaluate the internal consistency of the questionnaire form, the reliability coefficient (Cronbach Alpha) was calculated, and was found to be .884 .

Table 2

Reliability Statistics

\begin{tabular}{cc}
\hline Cronbach's Alpha & N of Items \\
\hline .884 & 62 \\
\hline
\end{tabular}

The reliability coefficients of all variables in the questionnaire were found not only to have values of high statistical significance, but to be satisfactory.

\begin{tabular}{lcc}
\hline Table 3 & \\
KMO and Bartlett's Test Statistics & \\
\hline \multicolumn{2}{l}{ KMO and Bartlett's Test } & .746 \\
\hline \multicolumn{2}{l}{ Kaiser-Meyer-Olkin Measure of Sampling Adequacy. } & 936.364 \\
Bartlett's Test of Sphericity & Approx. Chi-Square & 45 \\
& Df & .000 \\
\hline
\end{tabular}

Table 3 presents both the results of the KMO (.746) and Barlett's Test ( $p<$ $.01)$, which show that the sample size is adequate and that the data have a normal distribution respectively. While KMO values greater than .45 indicate that variables are suitable for conducting a factor analysis, a Bartlett's Test shows whether the relationship pattern among the variables is appropriate for conducting a factor analysis and whether or not results are statistically significant.

\begin{tabular}{|c|c|c|c|c|c|}
\hline \multirow{2}{*}{\multicolumn{6}{|c|}{$\begin{array}{l}\text { Table } 4 \\
\text { Demographic Characteristics of the Participants }\end{array}$}} \\
\hline & & & & & \\
\hline Age & & Frequency & Percent & Valid Percent & Cumulative Percent \\
\hline \multirow{20}{*}{ Valid } & 18.00 & 3 & 1.4 & 1.4 & 1.4 \\
\hline & 19.00 & 12 & 5.7 & 5.7 & 7.1 \\
\hline & 21.00 & 33 & 15.7 & 15.7 & 22.9 \\
\hline & 22.00 & 2 & 1.0 & 1.0 & 23.8 \\
\hline & 23.00 & 16 & 7.6 & 7.6 & 31.4 \\
\hline & 24.00 & 2 & 1.0 & 1.0 & 32.4 \\
\hline & 27.00 & 10 & 4.8 & 4.8 & 37.1 \\
\hline & 28.00 & 4 & 1.9 & 1.9 & 39.0 \\
\hline & 30.00 & 6 & 2.9 & 2.9 & 41.9 \\
\hline & 32.00 & 27 & 12.9 & 12.9 & 54.8 \\
\hline & 33.00 & 19 & 9.0 & 9.0 & 63.8 \\
\hline & 34.00 & 9 & 4.3 & 4.3 & 68.1 \\
\hline & 35.00 & 2 & 1.0 & 1.0 & 69.0 \\
\hline & 38.00 & 3 & 1.4 & 1.4 & 70.5 \\
\hline & 40.00 & 11 & 5.2 & 5.2 & 75.7 \\
\hline & 43.00 & 8 & 3.8 & 3.8 & 79.5 \\
\hline & 45.00 & 26 & 12.4 & 12.4 & 91.9 \\
\hline & 54.00 & 15 & 7.1 & 7.1 & 99.0 \\
\hline & 56.00 & 2 & 1.0 & 1.0 & 100.0 \\
\hline & Total & 210 & 100.0 & 100.0 & \\
\hline
\end{tabular}


In order to determine the grouping differences among the factors influencing entrepreneurship behaviors in corporate entrepreneurship models, a factor analysis was conducted. SPSS FOR Win.Ver.21 software program was used to conduct statistical analyses and make calculations.

\section{Results}

The distribution of participants' demographic characteristics:

\begin{tabular}{|c|c|c|c|c|c|}
\hline \multicolumn{6}{|l|}{ Table 5} \\
\hline \multicolumn{6}{|c|}{ Gender Characteristics of the Participants } \\
\hline Gender & & Frequency & Percent & Valid Percent & Cumulative Percent \\
\hline \multirow{3}{*}{ Valid } & male & 120 & 57.1 & 57.1 & 57.1 \\
\hline & female & 90 & 42.9 & 42.9 & 100.0 \\
\hline & Total & 210 & 100.0 & 100.0 & \\
\hline
\end{tabular}

\begin{tabular}{|c|c|c|c|c|c|}
\hline \multicolumn{6}{|c|}{ Table 6} \\
\hline \multicolumn{6}{|c|}{ Education Characteristics of the Participants } \\
\hline \multicolumn{2}{|c|}{ Education } & Frequency & Percent & Valid Percent & Cumulative Percent \\
\hline \multirow{5}{*}{ Valid } & High school & 56 & 26.7 & 26.7 & 26.7 \\
\hline & Bachelor's degree & 68 & 32.4 & 32.4 & 59.0 \\
\hline & Master's degree & 8 & 3.8 & 3.8 & 62.9 \\
\hline & Doctorate & 78 & 37.1 & 37.1 & 100.0 \\
\hline & Total & 210 & 100.0 & 100.0 & \\
\hline
\end{tabular}

\begin{tabular}{llcccc}
\hline $\begin{array}{l}\text { Table } 7 \\
\text { Titles of the Participants }\end{array}$ & & & & \\
\hline \multicolumn{7}{l}{ Title } & & Frequency & Percent & Valid Percent & Cumulative Percent \\
\hline \multirow{4}{*}{ Valid } & Doctor & 78 & 37.1 & 37.1 & 37.1 \\
& Nurse & 108 & 51.4 & 51.4 & 88.6 \\
& Other & 24 & 11.4 & 11.4 & 100.0 \\
& Total & 210 & 100.0 & 100.0 & \\
\hline
\end{tabular}

\begin{tabular}{llcccc}
\hline \multicolumn{2}{l}{$\begin{array}{l}\text { Table } 8 \\
\text { Participants'Positions }\end{array}$} & & & & \\
\hline \multirow{2}{*}{ Valid } & Manager & 62 & 29.5 & 29.5 & 29.5 \\
& Employee & 148 & 70.5 & 70.5 & 100.0 \\
& Total & 210 & 100.0 & 100.0 & \\
\hline
\end{tabular}

According to the demographics, $57.1 \%$ of the participants in the study are male and $42.9 \%$ are female. Moreover, $26.7 \%$ of the participants had graduated from high school, $32.4 \%$ had earned their bachelor's degree, $3.8 \%$ had earned a graduate degree, and $37.1 \%$ had earned a PhD. Regarding their positions, $37.1 \%$ of the respondents were doctors, $51.4 \%$ nurses, and $11.4 \%$ worked as other healthcare staff with in the hospital. In addition, $29.5 \%$ of the respondents had executive duties (shown as Manager in Table 8). 


\section{Factor Analysis Results}

\begin{tabular}{|c|c|c|}
\hline Table 9 & & \\
\hline KMO and Bartlett's Test & & \\
\hline KMO and Bartlett's Test & & \\
\hline Kaiser-Meyer-Olkin Measur & ing Adequacy. & .746 \\
\hline Bartlett's Test of Sphericity & Approx. Chi-Square & 936.364 \\
\hline & Df & 45 \\
\hline & Sig. & .000 \\
\hline
\end{tabular}

The KMO value (.746) indicates that the sample size in this study is adequate, and the Bartlett's test results $(p<.01)$ indicate that the data have a normal distribution.

\begin{tabular}{lcc}
\hline Table 10 & & \\
Communalities ${ }^{*}$ Extraction & Method: Principal & Component Analysis Communalities* \\
\hline & Initial & Extraction \\
\hline Growth & 1.000 & 0.884 \\
Creativity & 1.000 & 0.540 \\
Risk & 1.000 & 0.734 \\
Success & 1.000 & 0.595 \\
Communication & 1.000 & 0.573 \\
Resource & 1.000 & 0.792 \\
Rewarding & 1.000 & 0.842 \\
Structure & 1.000 & 0.749 \\
Autonomy & 1.000 & 0.588 \\
Support & 1.000 & 0.670 \\
\hline
\end{tabular}

As can seen from the communalities table, the study's variables are appropriate in terms of explaining the common variance in the common factor.

\begin{tabular}{ccccccc}
\hline \multicolumn{2}{l}{$\begin{array}{l}\text { Table } 11 \\
\text { Total Variance Explained }\end{array}$} & Extraction Method: Principal Component Analysis & Total Variance Explained \\
\hline \multirow{2}{*}{ Component } & \multicolumn{7}{c}{ Initial Eigenvalues } & \multicolumn{2}{c}{ Extraction Sums of Squared Loadings } \\
\cline { 2 - 7 } & Total & \% of Variance & Cumulative \% & Total & \% of Variance & Cumulative \% \\
\hline 1 & 4.132 & 41.322 & 41.322 & 4.132 & 41.322 & 41.322 \\
2 & 1.552 & 15.520 & 56.843 & 1.552 & 15.520 & 56.843 \\
3 & 1.283 & 12.835 & 69.677 & 1.283 & 12.835 & 69.677 \\
4 & 0.773 & 7.730 & 77.407 & & & \\
5 & 0.693 & 6.927 & 84.334 & & & \\
6 & 0.473 & 4.735 & 89.069 & & & \\
7 & 0.376 & 3.763 & 92.832 & & & \\
8 & 0.289 & 2.894 & 95.726 & & & \\
9 & 0.226 & 2.262 & 97.988 & & & \\
10 & 0.201 & 2.012 & 100.000 & & & \\
\hline
\end{tabular}

As can be seen from the Table 11, items are loaded on three factors. The total variance explained by the first factor is $41.32 \%$, the second factor explains $15.52 \%$ of the total variance, and the third factor explains $12.83 \%$ of the total variance. In total, 


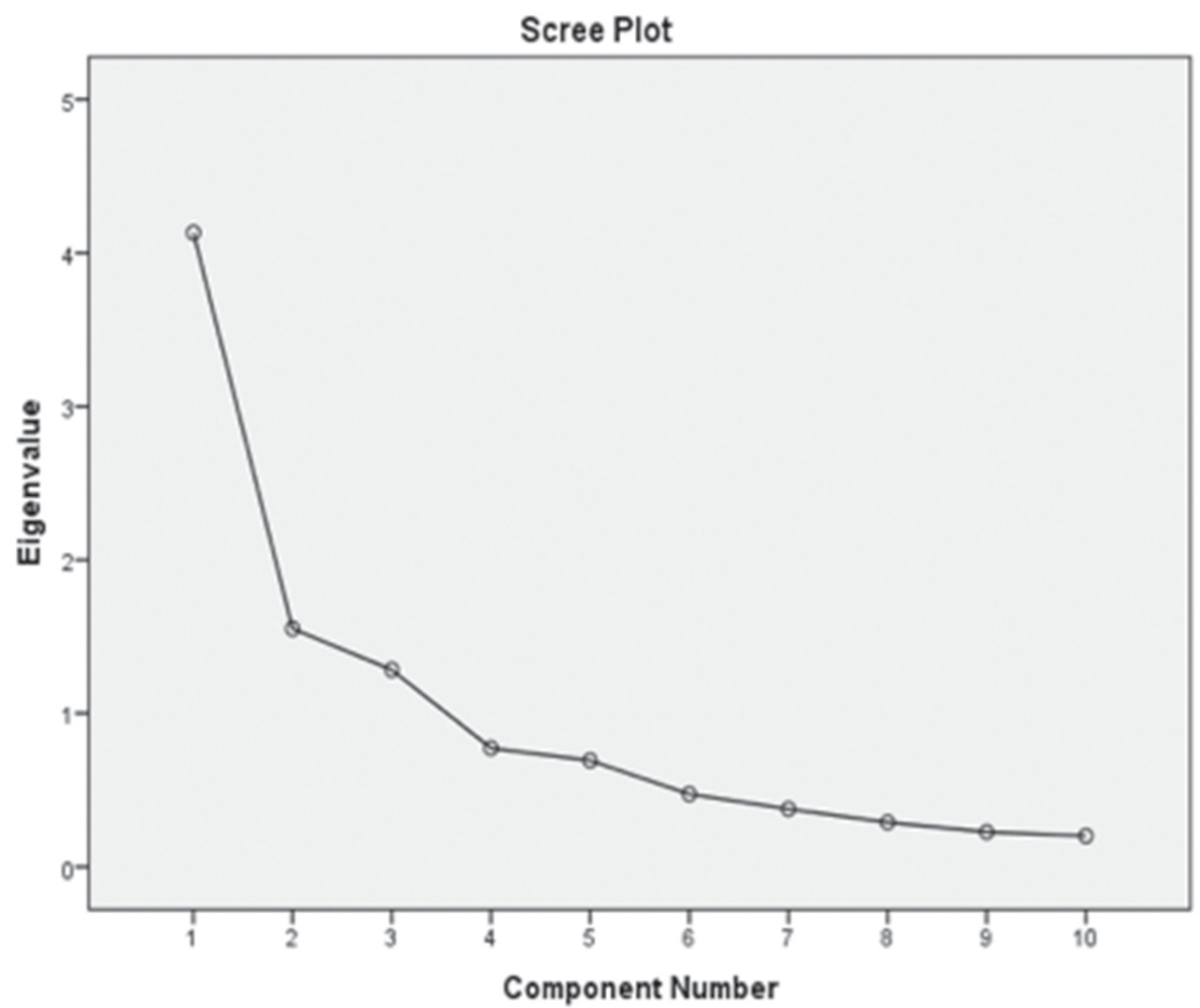

Figure 2: Scree plot.

the three factors emerging in the factor analysis explain $69.67 \%$ of the total variance, which represents a considerable part of the total variance.

After examining the scree plot graphic it can be stated that according to the total variance explained and graphical results items are loaded on three factors.

\begin{tabular}{|c|c|c|c|}
\hline \multicolumn{4}{|l|}{ Table 12} \\
\hline \multicolumn{4}{|c|}{ Component Matrix ${ }^{a^{*}}$} \\
\hline & \multicolumn{3}{|c|}{ Component } \\
\hline & 1 & 2 & 3 \\
\hline Resource & .778 & -.404 & .154 \\
\hline Autonomy & .761 & .028 & .092 \\
\hline Support & .760 & -.097 & -.289 \\
\hline Rewarding & .715 & .160 & -.552 \\
\hline Structure & .678 & -.535 & .042 \\
\hline Communication & .673 & -.071 & .340 \\
\hline Creativity & .580 & .405 & -.200 \\
\hline Success & .580 & -.028 & .508 \\
\hline Growth & .177 & .683 & .622 \\
\hline Risk & .492 & .656 & -.248 \\
\hline
\end{tabular}


Table 13

Rotated Total Variance Explained *Extraction Method: Principal Component Analysis

\begin{tabular}{|c|c|c|c|c|c|c|c|c|c|}
\hline \multirow[b]{2}{*}{ Component } & \multicolumn{3}{|c|}{ Initial Eigenvalues } & \multicolumn{3}{|c|}{$\begin{array}{c}\text { Extraction Sums of Squared } \\
\text { Loadings }\end{array}$} & \multicolumn{3}{|c|}{$\begin{array}{c}\text { Rotation Sums of Squared } \\
\text { Loadings }\end{array}$} \\
\hline & Total & $\begin{array}{c}\% \text { of } \\
\text { Variance }\end{array}$ & $\begin{array}{c}\text { Cumulative } \\
\%\end{array}$ & Total & $\begin{array}{c}\% \text { of } \\
\text { Variance }\end{array}$ & $\begin{array}{c}\text { Cumulative } \\
\%\end{array}$ & Total & $\begin{array}{c}\% \text { of } \\
\text { Variance }\end{array}$ & $\begin{array}{c}\text { Cumulative } \\
\%\end{array}$ \\
\hline 1 & 4.132 & 41.322 & 41.322 & 4.132 & 41.322 & 41.322 & 3.111 & 31.113 & 31.113 \\
\hline 2 & 1.552 & 15.520 & 56.843 & 1.552 & 15.520 & 56.843 & 2.427 & 24.273 & 55.386 \\
\hline 3 & 1.283 & 12.835 & 69.677 & 1.283 & 12.835 & 69.677 & 1.429 & 14.291 & 69.677 \\
\hline 4 & .773 & 7.730 & 77.407 & & & & & & \\
\hline 5 & .693 & 6.927 & 84.334 & & & & & & \\
\hline 6 & .473 & 4.735 & 89.069 & & & & & & \\
\hline 7 & .376 & 3.763 & 92.832 & & & & & & \\
\hline 8 & 289 & 2.894 & 95.726 & & & & & & \\
\hline 9 & .226 & 2.262 & 97.988 & & & & & & \\
\hline 10 & .201 & 2.012 & 100.000 & & & & & & \\
\hline
\end{tabular}

According to the rotated component matrix, which was obtained through factor rotation, items are loaded on three factors. Items in the first factor explain $31.11 \%$ of the total variance, items in the second factor explain $24.27 \%$ of the total variance, and items in the third factor explain $14.29 \%$ of the total variance.

\begin{tabular}{|c|c|c|c|}
\hline \multicolumn{4}{|l|}{ Table 14} \\
\hline \multirow{2}{*}{\multicolumn{4}{|c|}{$\begin{array}{l}\text { Rotated Component Matrix } * \text { Extraction Method: Principal Component Analysis and Rotation Method: } \\
\text { Varimax with Kaiser Normalization. }{ }^{a} \text { Rotation Converged in } 6 \text { Iterations }\end{array}$}} \\
\hline & & & \\
\hline \multicolumn{4}{|c|}{ Rotated Component Matrix*a } \\
\hline & \multicolumn{3}{|c|}{ Component } \\
\hline & 1 & 2 & 3 \\
\hline Resource & .869 & .168 & -.093 \\
\hline Structure & .815 & .101 & -.273 \\
\hline Communication & .689 & .177 & .259 \\
\hline Success & .656 & .046 & .403 \\
\hline Autonomy & .618 & .427 & .153 \\
\hline Rewarding & .280 & .843 & -.231 \\
\hline Risk & -.031 & .799 & .308 \\
\hline Creativity & .182 & .689 & .180 \\
\hline Support & .539 & .579 & -.209 \\
\hline Growth & .029 & .119 & .932 \\
\hline
\end{tabular}

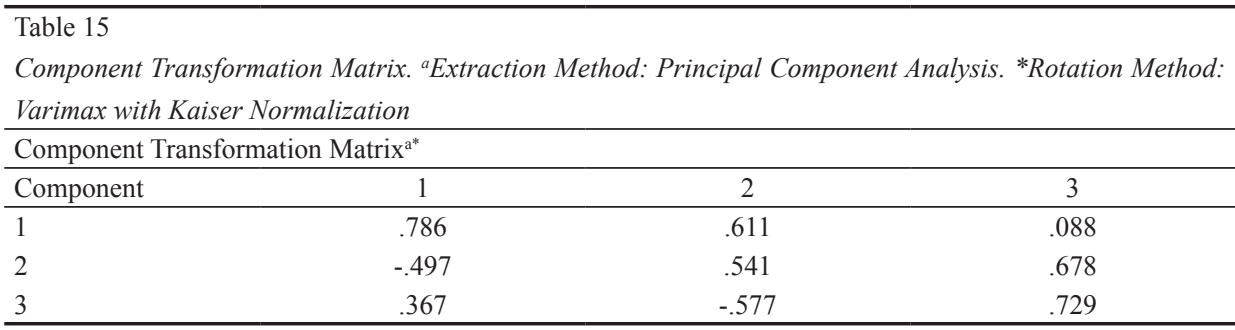


According to the rotated factor analysis results, the following variables were loaded on the first factor: resource, structure, communication, success, and autonomy; the following variables were loaded on the second factor: rewarding, risk, creativity, and support; and the following variable was loaded on the third factor: development. Therefore, the first factor was named "organizational characteristics" due to its inclusion of variables related to structure, the second factor was named "entrepreneurship characteristics," and the third factor was named "development."

\section{Discussion}

In this study, first, the concept of corporate entrepreneurship was evaluated Next the dimension of "innovation in services and processes," which is also included in the definitions offered by some of the pioneers of the entrepreneurship tendency approach (Drucker, 1984; Kuratko, 2001; Lumpkin \& Dess, 2001; Slevin \& Covin, 1990; Zahra, 2007), was examined. Finally, the perceptions toward corporate entrepreneurship held by healthcare workers employed in an organization supportive of innovation were attempted to be measured.

Entrepreneurship literature emphasizes that for the successful implementation of corporate entrepreneurship strategies, various organizational characteristics must be established within businesses. According to prior studies, which argue that corporate strategy is a managerial strategy used to foster entrepreneurial behavior among employees, competitive advantage will be achieved by producing and offering new products and services.

In order to survive over the long term and increase value by maintaining a competitive advantage, managers are required to identify and make use of opportunities in the environment, on the one hand, and to guide employees on the other. While doing the latter one, managers should posses an innovation-based strategic perspective. The underlying reason for this issue is based on the notion that just as organizations are forced to create new products and services, so are they forced to be effective and efficient in order to obtain a competitive advantage. To increase the value of healthcare services, organizations are required to be leaders of innovations. Innovations developed in the healthcare services will create more values for patients, and competitive advantage for organizations. Thus, providing more efficient and effective healthcare services may only be realized by developing new services. Therefore, corporate entrepreneurship will provide healthcare organizations with competitive advantage in the long term, just as it does to other businesses.

According to the results of the statistical analyses, there is no statistically significant difference between gender and one's perception toward corporate entrepreneurship. Moreover, the results suggest that there is not a statistically significant difference 
between education level and one's perception of corporate entrepreneurship. Therefore, these tables have not been included in the current study.

For the healthcare organization included in this study, it was determined that an intra-organizational entrepreneurship climate fostering corporate entrepreneurship was established. Furthermore, it was determined that employees' perceptions toward sufficient resources, healthy communication, support, and rewarding are positive. For the personal characteristics that determine entrepreneurship characteristics, perceptions toward creativity and risk taking were also found to be positive. Considering that the main aim of the current study is to provide empirical evidence to corporate entrepreneurship literature, it is possible to argue that, according to the results, organizational characteristics and entrepreneurship characteristics are two important factors, as it was to be expected considering the corporate entrepreneurship literature. Specifically, these results are consistent with prior studies on corporate entrepreneurship (Hornsby et al., 2002; Kuratko \& Hodgetts, 2001; Slevin \& Covin, 1990).

In order not only to survive over the long term, but to increase in value after having reached competitive advantage, the top management must continuously seek solutions to issues regarding potential new markets, potential innovations and their implementations, and future business activities. In order to increase the value of healthcare services managers of healthcare organizations are therefore required to determine entrepreneurial strategies that lead to innovations. Both "Entrepreneurial Management Style" and "Corporate Management Strategy" must be evaluated as management strategies.

For a successful implementation of corporate entrepreneurship strategies, managers must provide support to employees, resource allocations must be organized in such a way that provide incentives to workers, and continuous communication must be established within the organization. Individuals who feel a higher need for achievement must be encouraged to develop new ideas and to take risks by establishing appropriate rewarding mechanisms.

Consequently, this study aims to emphasize the importance of leading innovations, in addition to the knowledge and learning. Thus, an increase of the value of healthcare services in hospitals, in which services provided are directly related to human life, can be maintained. This study was done to determine which corporate entrepreneurship perceptions influence entrepreneur behaviors. Future studies including both a higher number of participants as well as those that analyze external factors influencing the healthcare sector might lead to more efficient results. 


\section{References}

Amabile T. M., \& Conti, R. (1999). Changes in the work environment for creativity during downsizing. The Academic Management Journal, 42(6), 630-640.

Antoncic, B., \& Hisrich, R. D. (2001). Intrapreneurship: Construct refinement and crosscultural validation. Journal of Business Venturing, 16(5), 495-527.

Block, Z., \& MacMillan, L. (1995). Corporate venturing: Creating new businesses within the firm. Boston, MA: Harvard Business School Press.

Covin, J. G., \& Miles, M. P. (1999). Corporate entrepreneurship and the pursuit of competitive advantage. Entrepreneurship Theory and Practice, 23(3), 48-57.

Dess, G. G., Lumpkin, G. T., \& McGee, J. (1999). Linking corporate entrepreneurship to strategy, structure and process: Suggested research directions. Entrepreneurship Theory and Practice, 23(3), 85-102.

Drucker, P. F. (1984). Our entrepreneurial economy. Harvard Business Review, 62(1), 58-64.

Floyd, S. W., \& Wooldridge, B. (1999). Knowledge creation and social networks in corporate entrepreneurship: The renewal of organizational capability. Entrepreneurship Theory and Practice, 23(3), 123-143.

Greene, P. G., Brush, C. G., \& Hart, M. M. (1999). The corporate venture champion: A resourcebased approach to role and process. Entrepreneurship Theory and Practice, 23(3), 103-122.

Guo, K. L. (2003). An assessment tool for developing healthcare managerial skills and roles. Journal of Healthcare Management, 48(6), 367-376.

Hamel, G., \& Prahalad, C. K. (1998). Competing for the future. Boston, MA: Harvard Business School Press.

Hayton, J. C., \& Kelley, D. J. (2006). A Competency-Based Framework For Promoting Corporate Entrepreneurship. Human Resource Management, 45(3), 407-427.

Hornsby, J. S., Kuratko, D. F., \& Zahra, S. A. (2002). Middle managers' perception of the internal environment for corporate entrepreneurship: Assessing a measurement scale. Journal of Business Venturing, 17(3), 253-273.

Hornsby, J. S., Naffziger, D. W., Kuratko, D. F., \& Montagno, R. V. (1993). An interactive model of corporate entrepreneurship process. Entrepreneurship Theory and Practice, 17(2), 29-38.

Kuratko, D. F. (2013). Entrepreneurship: Theory, process, and practice. Ohio, South Western: Cengage Learning.

Kuratko, D. F., \& Hodgetts, R. M. (2001). Entrepreneurship: A contemporary approach. Fort Worth: Harcourt College Publishers.

Lane, J., John, H., Marburger, III. J., \& Shipp, S. (2011). The science of science policy: A handbook, Kaye Fealing. Stanford, CA: Stanford University Press.

Lumpkin, G. T., \& Dess, G. G. (2001). Linking two dimensions of entrepreneurial orientation to firm performance: The moderating role of environment and industry life cycle. Journal of business Venturing, 16(5), 429-451.

Miles, R. E., Miles, G., \& Snow, C. C. (2006). Collaborative entrepreneurship: A business model for continuous innovation. Organizational Dynamics, 35(1), 1-11.

Pinchot III. G. (1986). Intrapreneuring: Why you don't have to leave the corporation to become an entrepreneur. New York, NY: Harper \& Row Publishers.

Porter, M. E., \& Teisberg, E. O. (2006). Redefining health care: Creating value-based competition on results. Boston, MA: Harvard Business School Press. 
Russel, R. D. (1999). Developing a process model of intrapreneurial systems: A cognitive mapping approach. Entrepreneurship Theory and Practice, 23(3), 65-84.

Slevin, D. P., \& Covin, J. G. (1990). Juggling entrepreneurial style and organizational structure: How to get your act together. Sloan Management Review, 31(2), 43-54.

Ülgen, H., \& Mirze, S. K. (2004). Issletmelerde stratejik yönetim [Strategic management in business]. İstanbul, Turkey: Literatür Yayıncılık.

Vesper, K. H. (1984). Three faces of corporate entrepreneurship: A pilot study. University of Washington, Graduate School of Business.

Wilkinson, T. J., \& Kannan, V. R. (2013). Strategic management in the 21st century (Vol. 1: The operational environment). Westport, CT: Praeger/ABC-Clio.

Zahra, S. A. (2007). Contextualizing theory building in entrepreneurship research. Journal of Business Venturing, 22(3), 443-452. 